\title{
The Effects of Covid-19 on Financial Statements: Some Insights from Italy through an International Literature Review
}

\author{
Veronica Tibiletti", Pier Luigi Marchini, Federico Bertacchini \\ Department of Economics and Management, University of Parma, Parma, Italy
}

Received July 24, 2021; Revised September 1, 2021; Accepted September 26, 2021

\begin{abstract}
Cite This Paper in the following Citation Styles
(a): [1] Veronica Tibiletti, Pier Luigi Marchini, Federico Bertacchini, "The Effects of Covid-19 on Financial Statements: Some Insights from Italy through an International Literature Review, "Universal Journal of Accounting and Finance, Vol. 9, No. 5, pp. 1033 - 1048, 2021. DOI: 10.13189/ujaf.2021.090514.
\end{abstract}

(b): Veronica Tibiletti, Pier Luigi Marchini, Federico Bertacchini (2021). The Effects of Covid-19 on Financial Statements: Some Insights from Italy through an International Literature Review. Universal Journal of Accounting and Finance, 9(5), 1033 - 1048. DOI: 10.13189/ujaf.2021.090514.

Copyright $\bigcirc 2021$ by authors, all rights reserved. Authors agree that this article remains permanently open access under the terms of the Creative Commons Attribution License 4.0 International License

\begin{abstract}
The uncertainty generated by the Covid-19 pandemic has influenced countless aspects of business management. In order to deal with the pandemic, managers had to make particularly complex choices regarding, for example, the cash management activities, investment decisions and workplace safety procedures. At the same time, the instability related to the performance and solvency of companies has made it necessary for companies to have adequate information disclosure, even more than that in the past. The Covid-19 pandemic has in fact increased the need for an effective communication about the main corporate events with all corporate stakeholders. Based on this premise, this study aims to highlight the main scientific contributions regarding the impact that the Covid-19 pandemic has had on accounting and on corporate financial reports. The analysis carried out led to the identification of five thematic areas: Policy, Corporate Social Responsibility, Disclosure, Financial Statements Data and Audit. Moreover, considering the importance of providing adequate disclosure in a period of great uncertainty, this paper proposes an analysis on the disclosure about the Covid-19 pandemic provided by the companies belonging to the FTSE MIB index of the Italian Stock Exchange. Following a preliminary quantitative analysis of the performance of these companies, a content analysis was carried out on the financial statements and the main documents attached to it, in order to verify the presence of references to the Covid-19 pandemic. It will be shown that the companies analyzed have made adequate disclosure of information regarding the emergency situation arising from the pandemic.
\end{abstract}

Keywords Covid-19, Financial Statements, Information Disclosure, Content Analysis, Literature Review

\section{Introduction}

The spread of the Covid-19 pandemic has affected health, the economy, transport, and numerous supply chains in various sectors and areas of the world [1], profoundly changing our economic and social life [2]. The restrictions that have been introduced in order to counter the spread of the pandemic have had significant consequences for the corporate world. The first half of 2020 was, in fact, marked by a full-fledged interruption of economic activity that resulted in a reduction in the demand for goods and services [3]. In April 2020, the International Monetary Fund had forecast a reduction in GDP in the Euro Area amounting to $-7.5 \%{ }^{1}$. However, in October 2020, this estimate was revised, bringing the contraction in the GDP of the Euro Area down to $-8.3 \%{ }^{2}$. In both of the Outlooks mentioned, Italy and Spain were the countries with the largest percentage contraction of

1 IMF, World Economic Outlook, April 2020: The Great Lockdown, 2020.

2 IMF, World Economic Outlook, October 2020: A Long and Difficult Ascent, 2020. 
GDP.

Governments around the world have, therefore, found themselves facing the emergency not only from a health standpoint, but also from an economic standpoint, and different policies have been introduced in fiscal, monetary, and business matters. However, what characterizes this precise historical moment is uncertainty, which is reflected in the estimates and conjectures that characterize the preparation of financial statements and, consequently, the disclosure of information for all corporate stakeholders.

The preparation of financial statements is, in fact, an activity whose function is to provide a representation of the company that is as accurate as possible. This search for objectivity, already rendered difficult by the subjective assessments made during the drafting phase, has been further undermined by the uncertainty linked to the spread of the Covid-19 pandemic. Indeed, the ambiguity linked to the resumption of economic activity has called into question the going concern assumption ${ }^{3}$, a fundamental proto-postulate for the preparation of financial statements. In Italy, for example, by means of Law no. 77 of 17 July $2020^{4}$, Parliament introduced the possibility of derogating, in certain situations, from what is indicated in Article 2423-bis regarding the going concern assumption. Even within the scientific literature, some studies are being geared towards investigating the difficulties inherent in going-concern assessment [4-6]. Although the going concern assumption is not the specific subject of analysis in this study, the impact it has had in terms of policy and scientific contributions helps us to understand the incredible effect of the Covid-19 pandemic on companies and the data shown in the financial statements. In fact, it has, in the medium term, raised doubts regarding the very survival of companies.

Despite their solidity, large listed companies also suffered important economic and financial repercussions following the pandemic. In fact, the Mediobanca Research Department published a research document in August 2020 that examined the economic and financial consequences of the pandemic on 25 industrial and service companies of the FTSE MIB index with reference to the first half of $2020^{5}$. Within the study, the companies were divided into four categories: energy / utilities, manufacturing, services, and oil. The oil sector recorded a reduction in turnover of 40.4\% compared to 30 June 2019 and an increase in financial debt of $11.5 \%$ compared to 31 December 2019. With reference to the same dates, the manufacturing sector recorded a $26 \%$ reduction in turnover and a $16 \%$ increase in financial debt. The services sector saw a reduction in turnover equal to $16.8 \%$ and an increase in financial debt equal to $10.6 \%$, and, lastly, the energy / utilities sector saw a reduction in turnover equal to $14.9 \%$ and an increase in

3 Art. 2423-bis, Italian Civil Code.

4 Conversion law with amendments to the Law Decree no. 34 of 19 May 2020.

5 "Impacts of COVID-19 pandemic on 1Q 2020 data for large industrial companies" (2020), Mediobanca Research Area, Briefing Note. financial debt equal to $4.6 \%$. The decline in turnover and the decline in EBIT are the worst figures of the last thirty years. All this has led to a deterioration in the financial stability of these companies.

As we will also see in the course of the analysis, the study of company performance, solvency, and the policies adopted to counter the negative economic effects of the pandemic have been a primary focus in the scientific literature. However, to the best of our knowledge, there are no contributions in the literature that have systematized the knowledge produced thus far on the subject. The purpose of this study is, therefore, to investigate the most avant-garde scientific contributions that have been produced regarding the impact that the Covid-19 pandemic has had on financial statements and on companies. To this end, the studies identified were divided according to the various topics covered, so as to give preferential treatment to the areas that remain under-researched.

Furthermore, given the fundamental role that financial reporting plays as far as corporate stakeholders are concerned, especially in periods of great uncertainty, we carried out an analysis of the disclosure provided by a sample of Italian listed companies in relation to the Covid 19 pandemic. This further analysis allowed us to understand the level of disclosure provided by the companies as reported in the various sections of the accounting documents. The importance of analyzing the information disclosure provided by the companies is clear both from the studies of large national and international institutes (e.g. IMF and Mediobanca Research Department, previously mentioned), and from the literature on the subject that will be analyzed later.

The results of the literature review, the methodology used, and the study of disclosure will, therefore, be illustrated in the following sections.

\section{Literature Review: an Analysis of the Contributions Produced on the Impact of Covid-19 on Accounting and Corporate Financial Reports}

Within this section, the various contributions produced regarding the impact of Covid-19 on the corporate world will be laid forth. The presentation of these studies will take place on the basis of the five areas identified in the analysis phase.

The process used to identify the scientific studies of the literature review was based on two distinct phases. In the first phase, the database for carrying out the literature review was Google Scholar. The keywords used in the research were based on the combination of the string "Covid-19" with one of the following strings: "Balance Sheet", "Income Statement", or "Financial Statement". Based on this research criterion, only the contributions including the impact of Covid-19 on corporate financial statements were selected. In the second phase of the process, we took into consideration articles published in the journals considered top-ranked by the Italian national 
classifications Anvur and Gev and the international classification Scimago. The journals within which to search were selected on the basis of the fact that they contained alternately within their name the strings "accounting", "finance", or "economy". Once the journals were selected, a search was carried out within their archives, using the same search strings used on Google Scholar. This next phase of the research process allowed us to have the certainty of including the articles published in these journals within our study. Also in this case, only the studies concerning the impact of Covid-19 on the balance sheet data were taken into consideration.

The publications identified through the two phases described above were, then, downloaded, read, and divided according to the different themes that they addressed. This process led to the identification of five different areas on the basis of which it is now possible to classify the studies present in the literature: Policy, Corporate Social Responsibility, Disclosure, Financial Statements Data, and Audit.

\subsection{Policy}

Governments around the world have assumed strategies and adopted policies that are not always homogeneous. Pirlot et al. [7] investigated the issue of fiscal policies that can be used in response to the crisis generated by the Covid-19 pandemic. Based on a subdivision of the crisis into three different phases, the authors indicated the objectives that fiscal policies should specifically pursue in each of them: the mitigation of the impact of the crisis; the stimulation of demand; and, in the last phase, the partial compensation of the costs incurred in the previous stages.

More specifically, Ahrens and Ferry [8] considered the role of accounting practices in the policies implemented by the UK government in response to the first wave of the Covid-19 pandemic. The authors stressed the importance of the role of accounting in allowing the government to correctly measure the extent of the crisis and the related policies to be implemented.

Taking on a different angle, Padhan and Prabheesh [9] analyzed the effects of Covid-19 on: the Stock Market, the exchange rate, and oil prices. The study is divided into two distinct parts: the first concerns the effects that have occurred thus far, and the second concerns the policies that can be adopted in response to the emergency. With reference to the first part, after an examination of the effects that have thus far manifested themselves at an economic level, the analysis was extended to the interrelationships between market yields, exchange rates, and the price of oil. The second part analyzed the different policies that governments can implement to counter the crisis resulting from the epidemiological emergency: (i) Monetary policy; (ii) Macro-prudential Regulation; (iii) Tax policy; and (iv) International political coordination.

De Vito and Gómez [10] analyzed two fiscal policies that can be implemented to reduce the risk that companies would not have the cash to meet their future commitments. These policies are called "bridge loans" and "tax deferrals".
The first allows for an increase in cash following the granting of long-term repayable loans guaranteed by the government. The "tax deferrals", on the other hand, allow companies to avoid reducing liquidity by suspending the payment of state taxes.

\subsection{Corporate Social Responsibility}

The negative consequences stemming from the epidemiological emergency have made it possible to focus on the need to pay increasing attention to what sustainability really means. As reported by Ekren et al. [11] problems related to sustainability that remain unresolved become unsustainable with disastrous and extremely costly consequences in the medium to long term. The study carried out by Lu and Wang [12] highlights the fact that the Covid-19 pandemic may nevertheless represent an opportunity for companies to review both their role within society and their priorities. Social responsibility requires companies to place stakeholders at the center of their activities by carrying out a variety of practices for them that must be properly accounted for. However, these issues are more widespread in large listed companies, characterized by a clear separation between management and ownership, while in European countries the main form of business is the small-medium enterprise in which ownership and management often coincide. Kraus et al. [13], in pondering the ability of small and medium-sized enterprises to cope with this emergency, found that a long-term perspective and a direct relationship with employees favored the implementation of policies guaranteeing social distancing and allowing, as much as possible, a continuation of work.

\subsection{Disclosure}

As far as the disclosure provided by companies is concerned, a topic that will also be taken up later in our analysis, Larcker et al. [14] studied disclosure as it relates to Covid-19 with reference to a sample of 3,644 US companies in the financial statements drawn up as of 31 December 2019. In the first months of the year, information concerning the Coronavirus in the reports of these companies was particularly scarce, and as of January 31 st only $0.7 \%$ had mentioned them. With the passage of time and with an ever-greater awareness of the seriousness of the situation, the number of companies referring to this emergency and the amount of information available has increased exponentially. In fact, as of April 30th, the percentage of companies making mention of pandemic related impacts was $86 \%$, and it is safe to assume that the reports for almost all the companies were made by the end of May.

The dissemination of information is particularly important for all stakeholders of the company, especially in this historical moment characterized by a high level of uncertainty: communicating and, in particular, communicating correctly is fundamental for companies. García-Sánchez et al. [15] highlighted how the Integrated 
Report (IR) is an appropriate means of communication for providing information at this time. Thanks to its flexibility and the lack of constraints and stringent rules, IR allows management to provide an image of a company's activities which is more extensive and, consequently, more accurate.

Loughran and McDonald [16] analyzed the disclosure statements provided by a sample of US listed companies on the risk factors that could negatively affect the share price. In fact, the authors took into consideration all the $10-\mathrm{K}$ reports starting from 2018, highlighting that less than $21 \%$ of them reported references to the possible negative effects on the stock deriving from a pandemic.

Tibiletti et al. [17] instead analyzed the information provided by a sample of Italian listed companies. The purpose of the research was to study how the management of the companies in the sample had perceived the dangers deriving from the Covid-19 pandemic, comparing the information disclosure provided in the financial statements as of 31.12.2019, with the corporate performance measured as of 30.06.2020. The study highlights a lack of consistency in the information provided by company management within the financial statements for the year 2019.

On the same topic, Honko et al. [18] questioned the quality of the information provided regarding the epidemiological emergency within the financial statements as of 31.12.2019 as well as in the half-yearly reports as of 30.6.2020. According to the authors, disclosure was often insufficient, making it difficult for stakeholders to understand the risk as far as these companies were concerned. The accurate communication of the effects of Covid-19 on the financial situation, on the results achieved, and, lastly, on liquidity is of critical importance.

Lastly, the Waclawik study [19] is one of the last presented and, therefore, uses very recent data to compare the results in the third quarter of 2020 with the same period in 2019 and 2018. The article analyzes the data provided by companies listed on the Warsaw Stock Exchange in order to determine the impact of Covid-19 on financial data for 2020. According to the research, from the point of view of financial positioning, the areas most affected by Covid-19 were the prospects of continuity, financial instruments, the credit / debit position claimed vis-à-vis the state, write-down of receivables and restatement of the items valued on the basis of what current values are. The author then concludes by arguing that Covid-19 has had a particularly significant economic impact that must be communicated with adequate information within the financial statements.

\subsection{Financial Statements Data}

Most of the studies identified through our analysis aimed to understand and analyze the impact of the Covid-19 pandemic on financial statements data. The interruption of the production process, a necessity following the introduction of measures to contain the pandemic, immediately generated concern for revenues and the solvency of companies. With this in mind, Schivardi and
Romano [20] proposed a method for determining the number of companies that would have become insolvent month after month in the aftermath of the interruption of production activities.

The issue of insolvency and company cash and cash equivalents has been addressed in several studies within the literature. In a research paper from Banco de Espana, Blanco et al. [21] underlined how indices and results of Spanish companies in the first three quarters of 2020 significantly worsened and how the same companies increased their cash and cash equivalents as a precaution.

Acharya and Steffen [22] analyzed the necessity of companies to resort to credit lines, in the face of reduced revenues, and the contextual risk that banking activities turn into non-performing loans (NPLs).

Similarly, Fahlenbrach et al. [23] studied how the reduction in revenues impacted the share price of firms differently on the basis of their financial flexibility. The results showed that companies with greater financial flexibility had higher equity returns following the revenue shock, thus underlining the similarities between the performance of companies in response to the epidemiological emergency and those of the same companies following the financial crisis that began in 2008.

Qin et al. [24] carried out a study based on data on the cash and cash equivalents of Chinese companies listed in the first quarter from 2014 to 2020 . The authors analyzed the impact of Covid-19 on the liquid assets of companies in different sectors, quantifying the changes in cash before and after the pandemic and trying to provide an explanation for these changes.

On the issue of costs for production activities, Matei [25], analyzing the half-yearly and annual financial statements of a sample of Romanian companies, highlighted an asset devaluation, an increase in debts, a reduction in revenues, and a slight reduction in costs. Therefore, it is clear that the values of tangible and intangible fixed assets as well as that of receivables and inventories decreased significantly. According to this study, the interruption of production activity led to a reduction in costs that was not proportional to the reduction in the positive components of income. Guerini et al. [26] noted in their study that, following the interruption of the production activity, the costs had been reduced with a different intensity. The purpose of this research was to verify the impact of Covid-19 on the financial statements of French companies through a simulated reduction of the liquidity of the companies themselves in order to test their solvency. In fact, the study analyzed the ability to meet future commitments according to four different scenarios ranging from a hypothesis of the complete absence of an epidemiological emergency to an extreme emergency scenario without a foreseeable endpoint.

Carletti et al. [27] sought to verify the impact of the liquidity crisis due to the epidemiological emergency on a sample of 80,972 Italian companies, grouping the results according to the different characteristics of the companies. The reduction in revenues due to the lockdown on the 
sample of selected companies was estimated in order to determine the reduction in costs, taxes, and profits, utilizing the 2018 financial statements as a baseline. Next, they estimated the injection of capital necessary for the companies to ensure their solvency. According to the authors, the overall effect of the epidemiological emergency was such that it caused an erosion of corporate capital. However, this impact was different according to the different characteristics of the companies, i.e., according to their (i) size, the small-sized companies are those most affected or those that record greater losses; (ii) leverage, the less capitalized companies become insolvent in shorter times; (iii) ownership, different results depending on whether they are listed and unlisted companies; (iv) the sector to which they belong, companies considered non-essential by the government performed worse than those that were able to continue their production activity and, lastly; (v) geography, the companies of Northern Italy were more affected than those of Southern Italy. The study, therefore, concludes by stating that the losses incurred by the epidemiological emergency have caused an erosion of the corporate capital influenced by their characteristics.

A performance analysis based on the location of the companies, carried out by Shen et al. [1], sought to predict the performance of listed Chinese companies in the first quarter of 2020 through an analysis of the data from their financial statements from 2013 to 2019. These forecasts were subsequently compared with the values actually recorded in the first quarter of 2020 and that therefore were impacted by the interruption of the production process due to the containment of the spread of the virus. The authors then tried to understand how the impact was different depending on the region to which they belonged. The analysis showed that the companies operating in the regions and sectors most affected suffered a stronger negative impact due to the specific restrictions enforced.

$\mathrm{Fu}$ and Shen [28] focused on the energy sector, one particularly affected by the pandemic, which includes all industries involved in the production and sale of energy, including the extraction, production, refining, and distribution of fuel. This is a sector strongly characterized by high fixed costs which, following the different national lockdowns, recorded a great reduction in revenues. The policies aimed at limiting the spread of the virus resulted in a significant reduction in the revenues of companies in this sector with a consequent contraction in the net income. These negative performances turned out to be even worse for those companies that had very significant goodwill among their corporate assets, recorded following the acquisition of third companies, necessarily subject to devaluation following the pandemic.

Taking matters a step further, Savova [29] analyzed the impacts of Covid-19 on the prospect of the going concern assumption. Covid-19 has certainly increased the degree of uncertainty around companies as far as their ability to continue to operate as a functioning entity is concerned. However, specific conclusions cannot be made on the basis of the financial statements closed as of 31.12.19 and the half-yearly reports as of 30.06.2020, in which the disclosure is not always sufficient for really understanding the risks associated with the company. It is, therefore, essential that investors constantly monitor the documents produced by companies in order to properly assess a company's ability to continue to operate as a functioning entity.

Lastly, Buera et al. [30], in their study, tried to verify how and to what extent the different lockdowns imposed by governments have affected the economy and how this has led to what is, effectively, a "deterioration" of balance sheet values.

\subsection{Audit}

The complications in the process of approving the 2019 financial statements, social distancing, and the economic performance of the companies subject to statutory audits also had repercussions on the audit process of 2019 financial statements and on the quality of the audit.

Albitar et al. [5] analyzed how a reduction in the quality of the audit can have significant repercussions on the confidence of stakeholders in the information contained in the accounting documents. In particular, the authors highlight how the restrictions and consequences of the Covid-19 pandemic can negatively impact audit fees, review procedures, the effort required to carry out a correct review, and, more generally, the quality of the review process.

Dohrer and Mayes [31], on the other hand, underline how essential it is to have adequate training and the correct technological equipment in order to be able to carry out remote audit activity properly.

Levy [32] stressed the need to carry out the audit while employing a healthy dose of professional skepticism, which must be the basis of any audit process and which takes on even greater value in periods of great instability. Moreover, the uncertainty related to the pandemic period requires the auditor to constantly question the validity of the audit evidence collected throughout the process.

Appelbaum et al. [33] highlighted some solutions that can be adopted using technology to address social distancing. In fact, they detail alternative methods for carrying out audit procedures such as warehouse inventories or the assessment of the state of fixed assets recorded in the financial statements. These activities, according to the authors, can be carried out with the aid of technological tools that, for example, make it possible to use real-time video streaming (e.g., Drones). Audit evidence, on the other hand, can be forwarded through technological devices: it is then the auditor's job to carefully analyze it to ascertain its validity. However, the various issues related to the different methods of collecting audit evidence and the complex economic situation lead to an increase in the perception of risk which, in turn, necessitates the use of creativity on the part of the auditor and flexibility on the part of the client.

Lastly, the latest study identified in this area was that of Kaka [34], who analyzed some of the practical challenges 
that auditors had to face during the review of financial statements, focusing on the areas of financial statements that required greater attention.
Table 1 lists the papers identified in this analysis and divides them into the relative thematic areas to which they belong.

Table 1. List of articles for literature review

\begin{tabular}{|c|c|c|c|}
\hline \multicolumn{4}{|c|}{ POLICY } \\
\hline AUTHOR/S & TITLE & $\begin{array}{c}\text { YEAR OF } \\
\text { PUBBLICATION }\end{array}$ & JOURNAL \\
\hline Ahrens T. and Ferry L. & $\begin{array}{l}\text { Accounting and accountability practices in } \\
\text { times of crisis: a Foucauldian perspective on } \\
\text { the UK government's response to COVID- } 19 \\
\text { for England }\end{array}$ & 2021 & $\begin{array}{l}\text { Accounting, Auditing \& } \\
\text { Accountability Journal }\end{array}$ \\
\hline $\begin{array}{l}\text { Collier R., Pirlot A. and } \\
\text { Vella J. }\end{array}$ & Tax policy and the COVID-19 crisis & 2020 & Intertax \\
\hline De Vito A. and Gómez J.P. & $\begin{array}{l}\text { Estimating the COVID-19 cash crunch: } \\
\text { Global evidence and policy }\end{array}$ & 2020 & $\begin{array}{c}\text { Journal of Accounting and Public } \\
\text { Policy }\end{array}$ \\
\hline $\begin{array}{l}\text { Padhan R. and Prabheesh } \\
\text { K.P. }\end{array}$ & $\begin{array}{c}\text { The economics of COVID-19 pandemic: A } \\
\text { survey }\end{array}$ & 2021 & Economic Analysis and Policy \\
\hline \multicolumn{4}{|c|}{ CORPORATE SOCIAL RESPONSIBILITY } \\
\hline AUTHOR/S & TITLE & $\begin{array}{c}\text { YEAR OF } \\
\text { PUBBLICATION }\end{array}$ & JOURNAL \\
\hline Ekren N. & $\begin{array}{l}\text { The impact of Covid-19 on the firms: results } \\
\text { of the thematic survey conducted by CSCPA } \\
\text { of Istanbul }\end{array}$ & 2021 & $\begin{array}{c}\text { International Journal of Commerce and } \\
\text { Finance }\end{array}$ \\
\hline $\begin{array}{c}\text { Kraus S., Clauss T., Breier } \\
\text { M., Gast J., Zardini A. and } \\
\text { Tiberius V. }\end{array}$ & $\begin{array}{c}\text { The economics of COVID-19: initial } \\
\text { empirical evidence on how family firms in } \\
\text { five European countries cope with the corona } \\
\text { crisis }\end{array}$ & 2020 & $\begin{array}{c}\text { International Journal of Entrepreneurial } \\
\text { Behavior \& Research }\end{array}$ \\
\hline Lu J. and Wang J. & $\begin{array}{l}\text { Corporate governance, law, culture, } \\
\text { environmental performance and CSR } \\
\text { disclosure: A global perspective }\end{array}$ & 2021 & $\begin{array}{l}\text { Journal of International Financial } \\
\text { Markets, Institutions \& Money }\end{array}$ \\
\hline \multicolumn{4}{|c|}{ DISCLOSURE } \\
\hline AUTHOR/S & TITLE & $\begin{array}{c}\text { YEAR OF } \\
\text { PUBBLICATION }\end{array}$ & JOURNAL \\
\hline $\begin{array}{l}\text { García-Sánchez I.M., Raimo } \\
\text { N., Marrone A. and } \\
\text { Vitolla F. }\end{array}$ & $\begin{array}{l}\text { How Does Integrated Reporting Change in } \\
\text { Light of COVID-19? A Revisiting of the } \\
\text { Content of the Integrated Reports }\end{array}$ & 2020 & Sustainability \\
\hline $\begin{array}{l}\text { Honko S., Remlein M., } \\
\text { Rowinska-Kral M. and } \\
\text { Swietla K. }\end{array}$ & $\begin{array}{c}\text { Effects of COVID-19 in the Financial } \\
\text { Statements of Selected Companies Listed in } \\
\text { Warsaw Stock Exchange }\end{array}$ & 2020 & European Research Studies Journal \\
\hline $\begin{array}{l}\text { Larcker D.F., Lynch B., } \\
\text { Tayan B. and Taylor D.J. }\end{array}$ & The spread of COVID-19 Disclosure & 2020 & Stanford Closer Look Series \\
\hline $\begin{array}{c}\text { Loughran T. and McDonald } \\
\text { B. }\end{array}$ & $\begin{array}{l}\text { Management Disclosure of Risk Factors and } \\
\text { COVID-19 }\end{array}$ & 2020 & SSRN Electronic Journal \\
\hline $\begin{array}{l}\text { Tibiletti V., Marchini P.L., } \\
\text { Gamba V. and Todaro D.L. }\end{array}$ & $\begin{array}{l}\text { The Impact of COVID-19 on Financial } \\
\text { Statements Results and Disclosure: First } \\
\text { Insights from Italian Listed Companies }\end{array}$ & 2021 & $\begin{array}{c}\text { Universal Journal of Accounting and } \\
\text { Finance }\end{array}$ \\
\hline Waclawik B. & $\begin{array}{c}\text { Corporate Reporting in the Time of } \\
\text { COVID-19: Analysis of Information } \\
\text { Disclosed by Selected Companies Listed on } \\
\text { the Warsaw Stock Exchange }\end{array}$ & 2021 & European Research Studies Journal \\
\hline
\end{tabular}




\begin{tabular}{|c|c|c|c|}
\hline \multicolumn{4}{|c|}{ FINANCIAL STATEMENT DATA } \\
\hline AUTHOR/S & TITLE & $\begin{array}{c}\text { YEAR OF } \\
\text { PUBBLICATION }\end{array}$ & $J O U R N A L$ \\
\hline Acharya V.V. and Steffen S. & $\begin{array}{l}\text { The Risk of Being a Fallen Angel and the } \\
\text { Corporate Dash for Cash in the Midst of } \\
\text { COVID }\end{array}$ & 2020 & The Review of Financial Studies \\
\hline $\begin{array}{l}\text { Blanco R., Mayordomo S., } \\
\text { Menéndez Pujadas Á. And } \\
\text { Mulino Rios M. }\end{array}$ & $\begin{array}{l}\text { The Impact of the Covid-19 Crisis on the } \\
\text { Financial Position of Non-Financial } \\
\text { Corporations in 2020: CBSO-based Evidence }\end{array}$ & 2020 & BancoDeEspana \\
\hline $\begin{array}{l}\text { Buera, F.J., Fattal-Jaef, R. } \\
\text { N., Hopenhayn, H., } \\
\text { Neumeyer, P.A. and Shin, Y. }\end{array}$ & The Economic Ripple Effects of COVID-19 & 2021 & $\begin{array}{c}\text { Working paper - National Bureau of } \\
\text { Economic Research }\end{array}$ \\
\hline $\begin{array}{l}\text { Carletti E., Oliviero T., } \\
\text { Pagano M., Pelizzon L. and } \\
\text { Subrahmanyam M.G. }\end{array}$ & $\begin{array}{l}\text { The COVID-19 Shock and Equity Shortfall: } \\
\text { Firm-Level Evidence from Italy }\end{array}$ & 2020 & $\begin{array}{c}\text { The Review of Corporate Finance } \\
\text { Studies }\end{array}$ \\
\hline $\begin{array}{l}\text { Fahlenbrach R., Rageth K. } \\
\text { and Stulz R.M. }\end{array}$ & $\begin{array}{l}\text { How Valuable Is Financial Flexibility when } \\
\text { Revenue Stops? Evidence from the } \\
\text { COVID-19 Crisis }\end{array}$ & 2020 & The Review of Financial Studies \\
\hline Fu M. and Shen H. & $\begin{array}{l}\text { COVID-19 and Corporate Performance in } \\
\text { the Energy Industry }\end{array}$ & 2020 & Energy RESEARCH LETTERS \\
\hline $\begin{array}{l}\text { Guerini M., Nesta L., Ragot } \\
\text { X. And Schiavo S. }\end{array}$ & $\begin{array}{l}\text { Firm liquidity and solvency under the } \\
\text { Covid-19 lockdown in France }\end{array}$ & 2020 & OFCE Policy brief \\
\hline Matei N.C. & $\begin{array}{c}\text { Impact of the Crisis Generated by Covid-19 } \\
\text { on Financial Reports Prepared in Accordance } \\
\text { with National Regulations }\end{array}$ & 2020 & Global Economic Observer \\
\hline $\begin{array}{l}\text { Qin X., Huang G., Shen H. } \\
\text { and Fu M. }\end{array}$ & $\begin{array}{l}\text { COVID-19 Pandemic and Firm-level Cash } \\
\text { Holding - Moderating Effect of Goodwill } \\
\text { and Goodwill Impairment }\end{array}$ & 2020 & Emerging Markets Finance and Trade \\
\hline Savova K. & $\begin{array}{l}\text { Global Impact of COVID } 19 \text { on the Concept } \\
\text { of "Going Concern" }\end{array}$ & 2021 & SHS Web of Conferences \\
\hline Schivardi F. and Romano G. & $\begin{array}{l}\text { A simple method to estimate firms' liquidity } \\
\text { needs during the Covid-19 crisis with an } \\
\text { application to Italy }\end{array}$ & 2020 & Covid Economics \\
\hline $\begin{array}{l}\text { Shen, H., Fu, M., Pan, H., } \\
\text { Yu, Z., and Chen, Y. }\end{array}$ & $\begin{array}{c}\text { The Impact of the COVID-19 Pandemic on } \\
\text { Firm Performance }\end{array}$ & 2020 & Emerging Markets Finance and Trade \\
\hline \multicolumn{4}{|c|}{ AUDIT } \\
\hline AUTHOR/S & TITLE & $\begin{array}{c}\text { YEAR OF } \\
\text { PUBBLICATION }\end{array}$ & JOURNAL \\
\hline $\begin{array}{l}\text { Albitar K., Gerged A.M., } \\
\text { Kikhia H. and Hussainey K. }\end{array}$ & $\begin{array}{l}\text { Auditing in times of social distancing: the } \\
\text { effect of COVID-19 on auditing quality }\end{array}$ & 2021 & $\begin{array}{c}\text { International Journal of Accounting \& } \\
\text { Information Management }\end{array}$ \\
\hline $\begin{array}{l}\text { Appelbaum D., Budnik S. } \\
\text { and Vasarhelyi M. }\end{array}$ & $\begin{array}{l}\text { Auditing and Accounting During and After } \\
\text { the COVID-19 Crisis }\end{array}$ & 2020 & The CPA Journal \\
\hline Dohrer B. and Mayes C. & $\begin{array}{l}\text { Auditing during COVID-19: } 6 \text { Areas to } \\
\text { Focus on; Practitioners and Their Clients Are } \\
\text { Facing Challenges They Have Never } \\
\text { Encountered Before }\end{array}$ & 2020 & Journal of Accountancy \\
\hline Kaka E.J. & Covid-19 and Auditing. & 2021 & $\begin{array}{c}\text { Journal of Applied Accounting and } \\
\text { Taxation }\end{array}$ \\
\hline Levy H.B. & $\begin{array}{l}\text { Financial Reporting and Auditing } \\
\text { Implications of the COVID-19 Pandemic }\end{array}$ & 2020 & The CPA Journal \\
\hline
\end{tabular}


From the analysis of the literature produced so far on the subject, it is clear the need to constantly monitor the financial data and the disclosure provided by companies, in order to effectively study the impact of the Covid-19 pandemic. The issues relating to Policy and Corporate Social Responsibility in fact require a medium-long term time horizon in order to be properly assessed. As previously stated, also for these reasons, this paper aimed to analyze the information disclosure provided by a sample of Italian listed companies.

\section{Methodology}

The analysis of the disclosure statements provided by companies on the Covid-19 issue was carried out by taking into consideration the 40 companies that are part of the FTSE MIB index, the most significant share index of the Italian Stock Exchange. The objective of the analysis was to understand the level of information disclosure provided both at a quantitative and qualitative level by the companies with the year-end date of 31 December 2020. For this reason, Mediobanca S.p.A. was excluded from the analysis (financial statements year-end as of 30 June 2020). The final sample subjected to analysis was, thus, comprised of 39 companies.

On the basis of this sample, a preliminary analysis was first carried out on the variation in the net income of the companies analyzed. This analysis allowed us to verify the economic performance of these companies in order to judge the information disclosure provided in a more correct and complete manner.
The study of the disclosure statements was based on a Content Analysis of the accounting documents of these companies. This analysis methodology is widely used in the literature for the study of corporate documents (e.g. [35-38]). Content Analysis is, in fact, considered a suitable research technique for analyzing communications, describing their content, and making deductions about their possible impact [39].

The documents considered in the analysis were as follows: the explanatory notes, the management report, the report of the board of statutory auditors, and the report of the auditing company. These reports were then downloaded from company sites and analyzed to highlight the presence of information references regarding the impact of Covid-19. As regards the explanatory notes and the management report, the presence of any references regarding the effects of Covid-19 was investigated within each individual section that makes up these documents. The reports of the board of statutory auditors and the independent auditors were, instead, considered as a whole: the presence ("Yes") or the absence ("No") of the information sought was highlighted at a document level and not at an individual section level.

Lastly, it should be noted that some companies did not have the report of the board of statutory auditors, as they have different governance systems. These companies have been classified using the term "Board", thus highlighting the presence of a different governance body than the Board of Statutory Auditors.

Table 2 summarizes the documents and sections analyzed.

Table 2. Documents and sections analyzed

\begin{tabular}{|c|c|c|}
\hline \multirow{5}{*}{ Explanatory Notes } & 1. Introductory Part & Yes/No \\
\hline & 2. Comment on specific terms of the financial statements & Yes/No \\
\hline & 3. Events occurring after the end of the financial year & Yes/No \\
\hline & 4. Indications of quantitative impacts & Yes/No \\
\hline & 5. Other & Yes/No \\
\hline \multirow{7}{*}{$\begin{array}{l}\text { Management } \\
\text { Report }\end{array}$} & 6. Introductory part & Yes/No \\
\hline & 7. Business outlook & Yes/No \\
\hline & 8. Events occurring after the end of the financial year & Yes/No \\
\hline & 9. Risk analysis & Yes/No \\
\hline & 10. Existence of a special paragraph for the covid-19 & Yes/No \\
\hline & 11. Indications of quantitative impacts & Yes/No \\
\hline & 12. Other & Yes/No \\
\hline $\begin{array}{c}\text { Board of Statutory Auditors } \\
\text { Report }\end{array}$ & 13. Entire document & Yes/No/Board \\
\hline Auditing Firm Report & 14. Entire document & $\mathrm{Yes} / \mathrm{No}$ \\
\hline
\end{tabular}


Table 3. Net income of the companies in the sample

\begin{tabular}{|c|c|c|c|}
\hline COMPANY & NET INCOME & NET INCOME & Change \% \\
\hline & $31 / 12 / 2019$ & $31 / 12 / 2020$ & $\%$ \\
\hline $\mathrm{A} 2 \mathrm{a}$ & 393.000 .000 & 368.000 .000 & $-6 \%$ \\
\hline Amplifon & 108.666 .000 & 101.004 .000 & $-7 \%$ \\
\hline Atlantia & 357.000 .000 & -1.641 .000 .000 & $-560 \%$ \\
\hline Azimut & 370.011 .000 & 381.690 .000 & $3 \%$ \\
\hline Banca Generali & 272.122 .000 & 274.894 .000 & $1 \%$ \\
\hline Banca Mediolanum & 565.432 .000 & 434.462 .000 & $-23 \%$ \\
\hline Banco Bpm & 781.437 .000 & 16.632 .000 & $-98 \%$ \\
\hline Bper Banca & 394.452 .000 & 270.667 .000 & $-31 \%$ \\
\hline Buzzi Unicem & 385.910 .000 & 560.472 .000 & $45 \%$ \\
\hline Campari & 308.400 .000 & 186.900 .000 & $-39 \%$ \\
\hline Cnh Industrial & 906.000 .000 & -695.000 .000 & $-177 \%$ \\
\hline Diasorin & 175.735 .000 & 248.296 .000 & $41 \%$ \\
\hline Enel & 3.476 .000 .000 & 3.622 .000 .000 & $4 \%$ \\
\hline Eni & 155.000 .000 & -8.628 .000 .000 & $-5666 \%$ \\
\hline Exor & 8.915 .000 .000 & 1.000 .000 & $-100 \%$ \\
\hline Ferrari & 698.708 .000 & 608.880 .000 & $-13 \%$ \\
\hline Finecobank & 288.365 .000 & 323.571 .000 & $12 \%$ \\
\hline Generali Ass & 2.939 .000 .000 & 2.032 .000 .000 & $-31 \%$ \\
\hline Hera & 402.000 .000 & 322.800 .000 & $-20 \%$ \\
\hline Interpump Group & 180.602 .000 & 173.271 .000 & $-4 \%$ \\
\hline Intesa Sanpaolo & 4.172 .000 .000 & 3.285 .000 .000 & $-21 \%$ \\
\hline Inwit & 139.313 .769 & 156.666 .767 & $12 \%$ \\
\hline Italgas & 423.599 .000 & 403.626 .000 & $-5 \%$ \\
\hline Leonardo & 822.000 .000 & 243.000 .000 & $-70 \%$ \\
\hline Moncler & 358.685 .000 & 300.351 .000 & $-16 \%$ \\
\hline Nexi & 136.086 .000 & 129.308 .000 & $-5 \%$ \\
\hline Pirelli \& C & 457.697 .000 & 42.673 .000 & $-91 \%$ \\
\hline Poste Italiane & 1.342 .000 .000 & 1.206 .000 .000 & $-10 \%$ \\
\hline Prysmian & 296.000 .000 & 174.000 .000 & $-41 \%$ \\
\hline Recordati Ord & 368.866 .000 & 355.027 .000 & $-4 \%$ \\
\hline Saipem & 98.000 .000 & -1.117 .000 .000 & $-1240 \%$ \\
\hline Snam & 1.090 .000 .000 & 1.101 .000 .000 & $1 \%$ \\
\hline Stellantis & 6.630 .000 .000 & 24.000 .000 & $-100 \%$ \\
\hline Stmicroelectronics & 388.000 .000 & 696.000 .000 & $79 \%$ \\
\hline Telecom Italia & 1.242 .000 .000 & 7.352 .000 .000 & $492 \%$ \\
\hline Tenaris & 731.258 .000 & -642.417 .000 & $-188 \%$ \\
\hline Terna & 763.900 .000 & 795.300 .000 & $4 \%$ \\
\hline Unicredit & 3.373 .000 .000 & -2.785 .000 .000 & $-183 \%$ \\
\hline Unipol & 1.086 .600 .000 & 864.100 .000 & $-20 \%$ \\
\hline Average & 1.021 .560 .122 & 456.978.815 & $-196,54 \%$ \\
\hline
\end{tabular}

\section{Results of the Analysis of the Disclosure Statements}

A preliminary analysis carried out on the net income of the companies in the sample allowed us to ascertain, at least in part, the economic impact of Covid-19 on corporate performance and, therefore, the disclosure.

Table 3 summarizes the quantitative data collected. Out of a total of 39 companies analyzed, only 11 achieved an operating result that as of $31 / 12 / 2020$ was higher than that 
of $31 / 12 / 2019$. The average contraction in the operating results of the companies in the sample is equal to $-196.54 \%$, although this figure is strongly influenced by some outlier values (e.g., Eni, Saipem, and Atlantia). The company that obtained the best positive change in net income is Telecom Italia SpA. The social distancing imposed by the pandemic has, in fact, favored the telecommunications sector to which this company belongs. An analysis of the results confirms the negative performance of the companies in the sample and, consequently, the need to provide, from a qualitative point of view, financial reporting capable of explaining these results and describing the transactions carried out in order to mitigate the negative effects of the pandemic. Qualitative and quantitative information are, indeed, complementary to each other, and, especially in a period of crisis, an accurate description of events and impacts is essential.

Following a preliminary analysis of the operating results of the companies in the sample, a Content Analysis was performed to understand the disclosure provided in qualitative terms on the impact of the Covid-19 pandemic. Table 4 shows the results of the analysis that was conducted. In the explanatory notes, and, specifically, in the first two sections of which it is comprised, it was possible to highlight a significant disclosure provided by the sample of companies analyzed. In the "Introductory Part" of this document, $87 \%$ of the companies analyzed made reference to the pandemic, while, in the "Comment on specific balance sheet items" section, $82 \%$ of the companies referred to Covid-19 in the explanations accompanying the data shown in the financial statements. Of interest is the data relating to the number of companies that have recalled the pandemic in the section "Events that occurred after the end of the financial year". In this instance, in fact, only 2 out of 39 companies made a direct reference to the pandemic in this section. The management report undoubtedly represents the document in which the greatest disclosure was made regarding the emergency situation. In fact, $92 \%$ of the companies in the sample presented a special paragraph within the document in which the topic of the Covid-19 pandemic was addressed. In addition, in the "Introductory Part" and in the "Risk Analysis" of the document, $95 \%$ and $92 \%$, respectively, of the companies in the sample referred to the state of emergency caused by Covid- 19 .

With regards to the Report of the Board of Statutory Auditors, $100 \%$ of the documents analyzed presented a reference to Covid-19. In order to correctly interpret this result, it is necessary to remember that the Board of Statutory Auditors is not present in all the companies in the sample, due to the foreign registered office and the different governance systems of some of the companies. The report of the auditing firm is the document within which the fewest references to the Covid-19 pandemic were made. Only $44 \%$ of the documents analyzed presented a specific reference, quantitative or qualitative, to the focus of our research. Appendix A shows the analytical information collected for each company in the sample.

\section{Conclusions}

The emergence of the Covid-19 pandemic has seriously affected all economies and posed challenges for businesses and individuals. The unexpected interruption of economic activities was a moment of critical importance for companies that had to reshape their investments, their action on the market, and, in many cases, their business models. However, despite the timely countermeasures implemented by companies and the governments of various countries, the protracted health emergency has led to considerable uncertainty regarding the economic results of companies and their future solvency. Within the scientific literature, there are many studies that have already attempted to analyze the impact of the Covid-19 pandemic on companies and their activities from a variety of different points of view. Our analysis demonstrates how the issues relating to solvency and corporate performance have been dealt with in previous research. However, further studies still need to be conducted regarding the impact that the pandemic has had on corporate social responsibility policies, the effects of government policies, and the changes that have occurred in the corporate auditing process. Furthermore, gaining an understanding of the long-term effects that this emergency has generated on corporate business models by individuating the common elements among the companies that have reacted better than others to the economic shock caused by Covid-19 will be of critical importance going forward. Within this context, the need to provide appropriate information disclosure by the companies in order to correctly communicate the influence that the Covid-19 pandemic has had on the data shown in the financial statements to all corporate stakeholders is, likewise, blatantly evident. Precisely for this reason, our analysis took into consideration the disclosure statements of the companies that are part of the FTSE MIB index of the Italian Stock Exchange 
Table 4. Disclosure statements in accounting documents

\begin{tabular}{|c|c|c|c|c|c|c|c|c|}
\hline \multirow{2}{*}{ Paragraphs analyzed } & \multicolumn{2}{|c|}{ Explanatory notes } & \multicolumn{2}{|c|}{ Report on operations } & \multicolumn{2}{|c|}{$\begin{array}{c}\text { Report of the Board of Statutory } \\
\text { Auditors }\end{array}$} & \multicolumn{2}{|c|}{ Report of the Independent Auditors } \\
\hline & $\begin{array}{l}\text { Companies that } \\
\text { make references }\end{array}$ & $\%$ & $\begin{array}{l}\text { Companies that } \\
\text { make references }\end{array}$ & $\%$ & $\begin{array}{l}\text { Companies that make } \\
\text { references }\end{array}$ & $\%$ & $\begin{array}{l}\text { Companies that } \\
\text { make references }\end{array}$ & $\%$ \\
\hline 1. INTRODUCTORY PART & 34 & $87 \%$ & & & & & & \\
\hline $\begin{array}{l}\text { 2. COMMENTS ON SPECIFIC } \\
\text { BALANCE SHEET ITEMS }\end{array}$ & 32 & $82 \%$ & & & & & & \\
\hline $\begin{array}{l}\text { 3. EVENTS AFTER THE END OF } \\
\text { THE FINANCIAL YEAR }\end{array}$ & 2 & $5 \%$ & & & & & & \\
\hline $\begin{array}{l}\text { 4. QUANTITATIVE IMPACT } \\
\text { INDICATIONS }\end{array}$ & 29 & $74 \%$ & & & & & & \\
\hline 5. OTHER & 0 & $0 \%$ & & & & & & \\
\hline 6. INTRODUCTORY PART & & & 37 & $95 \%$ & & & & \\
\hline 7. BUSINESS OUTLOOK & & & 23 & $59 \%$ & & & & \\
\hline $\begin{array}{l}\text { 8. EVENTS AFTER THE END OF } \\
\text { THE FINANCIAL YEAR }\end{array}$ & & & 7 & $18 \%$ & & & & \\
\hline 8. RISK ANALYSIS & & & 36 & $92 \%$ & & & & \\
\hline $\begin{array}{l}\text { 10. EXISTENCE OF A SPECIAL } \\
\text { PARAGRAPH RE COVID }\end{array}$ & & & 36 & $92 \%$ & & & & \\
\hline $\begin{array}{l}\text { 11. QUANTITATIVE IMPACT } \\
\text { INDICATIONS }\end{array}$ & & & 29 & $74 \%$ & & & & \\
\hline 12. OTHER & & & 2 & $5 \%$ & & & & \\
\hline 13. YES / NO / BOARD & & & & & $32 *$ & $100 \%$ & & \\
\hline 14. YES / NO & & & & & & & 17 & $44 \%$ \\
\hline
\end{tabular}

* 32 out of 32 companies that have a board of statutory auditors within their governance system. 
The study conducted enables us to state that, following the contraction of the net income highlighted in our preliminary analysis, the sample analyzed provided adequate disclosure information within the various documents that make up the financial statements. In fact, regardless of the sector to which they belong, the companies analyzed have always provided a satisfactory level of disclosure, even if the degree of analyticity found was different.

Within the accounting documents, the effects of the Covid-19 pandemic were taken into consideration both in the analysis of the economic and financial results achieved and in the analysis of business risks. In fact, as previously stated, the $92 \%$ of the reports on operations analyzed mentioned the Covid-19 in the section dedicated to risk analysis, while the $74 \%$ of them referred to the pandemic in the "Quantitative impact indications" section. However, it is necessary to underline that the economic and financial risks deriving from the prolongation of the emergency are difficult to predict and strongly linked to the results achieved in the healthcare sector. Nevertheless, it is necessary to reiterate that the information disclosure provided represented an element of fundamental importance for all corporate stakeholders, as it contributed to the correct interpretation of corporate results.
As far as the Report of the independent auditors is concerned, the reason for the lower percentage of references to the pandemic can be found in the objectives of this document. The auditing firm must, in fact, certify the absence of significant errors and certify that the financial statements clearly, truthfully, and correctly represent the assets, liabilities, and economic and financial situation of the company. Therefore, the references made refer to the interpretation and judgment of the economic and financial performance of the companies analyzed, for which account was taken, in the evaluation of the emergency situation generated by the pandemic.

Our research has some limitations. First of all, the sample of companies analyzed, although significant, is numerically limited. Future research will therefore have to consider a larger sample of companies in order to obtain more representative results. Secondly, the literature review was developed taking into consideration only the scientific contributions produced in relation to the effects of Covid-19 on corporate financial statements. It will therefore be necessary to carry out a review of the literature that examines a greater number of elements, considering the countless consequences of the pandemic on the corporate world. 


\section{Appendix A}

\begin{tabular}{|c|c|c|c|c|c|c|c|c|c|c|c|c|c|c|}
\hline & \multicolumn{5}{|c|}{ EXPLANATORY NOTE } & \multicolumn{7}{|c|}{ MANAGEMENT REPORT } & \multirow{2}{*}{$\begin{array}{c}\begin{array}{c}\text { Report of } \\
\text { the Board of } \\
\text { Statutory } \\
\text { Auditors }\end{array} \\
\text { Yes / No/ Board }\end{array}$} & \multirow{2}{*}{$\begin{array}{c}\text { Report o } \\
\text { the } \\
\text { Auditing } \\
\text { Firm }\end{array}$} \\
\hline & $\begin{array}{l}\text { Introductory } \\
\text { Part } \\
\text { Supplementary } \\
\text { Note }\end{array}$ & $\begin{array}{c}\text { Comments On Specific } \\
\text { Items Of The Balance } \\
\text { Sheet }\end{array}$ & $\begin{array}{l}\text { Events Occurred } \\
\text { After The End } \\
\text { Of The Year }\end{array}$ & $\begin{array}{c}\text { Indication Of } \\
\text { Quantitative } \\
\text { Impacts }\end{array}$ & Other & $\begin{array}{l}\text { Introductory } \\
\text { Part }\end{array}$ & $\begin{array}{c}\text { Forseeable } \\
\text { Evolution Of } \\
\text { Management }\end{array}$ & $\begin{array}{c}\text { Events } \\
\text { Occurred } \\
\text { After The End } \\
\text { Of The Year }\end{array}$ & $\begin{array}{c}\text { Risk } \\
\text { Analysis }\end{array}$ & $\begin{array}{l}\text { Existence Of } \\
\text { Paragraph } \\
\text { Re Covid }\end{array}$ & $\begin{array}{c}\text { Indications } \\
\text { Of } \\
\text { Quantitative } \\
\text { Impacts }\end{array}$ & Other & & \\
\hline A2a & 1 & 1 & 0 & 1 & 0 & 1 & 1 & 0 & 1 & 1 & 1 & 0 & YES & YES \\
\hline Amplifon & 1 & 1 & 0 & 1 & 0 & 1 & 1 & 0 & 1 & 1 & 1 & 0 & YES & NO \\
\hline Atlantia & 1 & 1 & 0 & 0 & 0 & 1 & 1 & 0 & 1 & 1 & 0 & 0 & YES & YES \\
\hline Azimut & 1 & 1 & 0 & 0 & 0 & 1 & 0 & 0 & 1 & 1 & 0 & 0 & YES & NO \\
\hline $\begin{array}{c}\text { Banca } \\
\text { Generali }\end{array}$ & 1 & 0 & 0 & 1 & 0 & 1 & 1 & 0 & 1 & 1 & 1 & 0 & YES & NO \\
\hline $\begin{array}{c}\text { Banca } \\
\text { Mediolanum }\end{array}$ & 1 & 1 & 0 & 1 & 0 & 1 & 1 & 0 & 1 & 1 & 0 & 1 & YES & NO \\
\hline Banco Bpm & 1 & 1 & 0 & 1 & 0 & 1 & 1 & 0 & 1 & 1 & 1 & 0 & YES & YES \\
\hline Bper Banca & 1 & 1 & 0 & 1 & 0 & 1 & 0 & 0 & 1 & 1 & 1 & 0 & YES & YES \\
\hline Buzzi Unicem & 1 & 1 & 0 & 1 & 0 & 1 & 1 & 1 & 1 & 0 & 0 & 0 & YES & NO \\
\hline Campari & 1 & 1 & 0 & 1 & 0 & 1 & 0 & 0 & 1 & 1 & 1 & 0 & BOARD & YES \\
\hline $\begin{array}{c}\text { Cnh } \\
\text { Industrial }\end{array}$ & 1 & 1 & 0 & 1 & 0 & 1 & 0 & 0 & 1 & 1 & 1 & 0 & BOARD & YES \\
\hline Diasorin & 0 & 1 & 0 & 1 & 0 & 1 & 1 & 1 & 1 & 1 & 1 & 0 & YES & NO \\
\hline Enel & 1 & 1 & 0 & 0 & 0 & 1 & 1 & 0 & 1 & 1 & 1 & 0 & YES & $\mathrm{NO}$ \\
\hline Eni & 1 & 1 & 0 & 1 & 0 & 1 & 0 & 0 & 1 & 1 & 1 & 0 & YES & YES \\
\hline Exor & 1 & 1 & 0 & 1 & 0 & 1 & 1 & 1 & 1 & 1 & 1 & 0 & BOARD & YES \\
\hline Ferrari & 1 & 1 & 0 & 0 & 0 & 0 & 1 & 1 & 1 & 1 & 1 & 0 & BOARD & YES \\
\hline
\end{tabular}




\begin{tabular}{|c|c|c|c|c|c|c|c|c|c|c|c|c|c|c|}
\hline Finecobank & 1 & 1 & 0 & 1 & 0 & 1 & 1 & 0 & 1 & 1 & 0 & 0 & YES & YES \\
\hline Generali Ass & 1 & 1 & 0 & 1 & 0 & 1 & 1 & 1 & 1 & 1 & 1 & 0 & YES & $\mathrm{NO}$ \\
\hline Hera & 1 & 0 & 0 & 0 & 0 & 1 & 0 & 1 & 1 & 1 & 1 & 0 & YES & $\mathrm{NO}$ \\
\hline $\begin{array}{c}\text { Interpump } \\
\text { Group }\end{array}$ & 0 & 1 & 0 & 1 & 0 & 1 & 0 & 0 & 0 & 0 & 1 & 0 & YES & NO \\
\hline $\begin{array}{c}\text { Intesa } \\
\text { Sanpaolo }\end{array}$ & 1 & 1 & 0 & 1 & 0 & 1 & 1 & 0 & 1 & 1 & 1 & 0 & YES & YES \\
\hline Inwit & 1 & 0 & 0 & 0 & 0 & 1 & 0 & 0 & 1 & 1 & 0 & 0 & YES & NO \\
\hline Italgas & 1 & 1 & 0 & 1 & 0 & 1 & 0 & 0 & 0 & 1 & 0 & 0 & YES & NO \\
\hline Leonardo & 0 & 1 & 0 & 1 & 0 & 1 & 1 & 0 & 1 & 1 & 1 & 0 & YES & NO \\
\hline Moncler & 1 & 1 & 0 & 1 & 0 & 1 & 1 & 0 & 1 & 1 & 1 & 0 & YES & NO \\
\hline Nexi & 1 & 0 & 0 & 0 & 0 & 1 & 1 & 0 & 1 & 1 & 0 & 0 & YES & YES \\
\hline Pirelli \& C & 1 & 1 & 0 & 1 & 0 & 1 & 0 & 0 & 1 & 1 & 1 & 0 & YES & YES \\
\hline Poste Italiane & 0 & 1 & 0 & 1 & 0 & 1 & 0 & 1 & 1 & 1 & 1 & 0 & YES & YES \\
\hline Prysmian & 1 & 0 & 0 & 1 & 0 & 0 & 0 & 0 & 1 & 1 & 1 & 0 & YES & NO \\
\hline $\begin{array}{l}\text { Recordati } \\
\text { Ord }\end{array}$ & 0 & 1 & 1 & 1 & 0 & 1 & 1 & 0 & 1 & 1 & 1 & 0 & YES & NO \\
\hline Saipem & 1 & 1 & 1 & 1 & 0 & 1 & 0 & 0 & 1 & 1 & 1 & 0 & YES & NO \\
\hline Snam & 1 & 1 & 0 & 1 & 0 & 1 & 1 & 0 & 1 & 1 & 1 & 0 & YES & NO \\
\hline Stellantis & 1 & 0 & 0 & 0 & 0 & 1 & 0 & 0 & 1 & 1 & 1 & 0 & BOARD & YES \\
\hline $\begin{array}{l}\text { Stmicroelectr } \\
\text { onics }\end{array}$ & 1 & 1 & 0 & 1 & 0 & 1 & 0 & 0 & 1 & 0 & 0 & 0 & BOARD & YES \\
\hline $\begin{array}{c}\text { Telecom } \\
\text { Italia }\end{array}$ & 1 & 1 & 0 & 1 & 0 & 1 & 1 & 0 & 1 & 1 & 1 & 0 & YES & NO \\
\hline Tenaris & 1 & 0 & 0 & 0 & 0 & 1 & 1 & 0 & 1 & 1 & 0 & 0 & BOARD & NO \\
\hline Terna & 1 & 1 & 0 & 1 & 0 & 1 & 0 & 0 & 0 & 1 & 1 & 0 & YES & NO \\
\hline Unicredit & 1 & 1 & 0 & 1 & 0 & 1 & 1 & 0 & 1 & 1 & 1 & 1 & YES & YES \\
\hline Unipol & 1 & 1 & 0 & 0 & 0 & 1 & 1 & 0 & 1 & 1 & 1 & 0 & YES & $\mathrm{NO}$ \\
\hline
\end{tabular}




\section{REFERENCES}

[1] Shen, H., Fu, M., Pan, H., Yu, Z., and Chen, Y. "The Impact of the COVID-19 Pandemic on Firm Performance." Emerging Markets Finance and Trade, Vol. 56, No. 10, 2020, pp. 2213-2230. https://doi.org/10.1080/1540496X.2020.178 5863.

[2] Brammer, S., Branicki, L., and Linnenluecke, M. K. "COVID-19, Societalization, and the Future of Business in Society." Academy of Management Perspectives, Vol. 34, No. 4, 2020, pp. 493-507. https://doi.org/10.5465/amp.2019 .0053 .

[3] Di Nardo, T., De Luca, R., Lucido, N., and Scardocci, G. Osservatorio Sui Bilanci Delle SRL 2018 e Stime 2020 Sul Fatturato Delle Società Di Capitali.

[4] Gray, G. L., and Alles, M. G. "Measuring a Business's Grit and Survivability When Faced with 'Black Swan' Events Like the Coronavirus Pandemic." Journal of Emerging Technologies in Accounting, Vol. 18, No. 1, 2021, pp. 195204. https://doi.org/10.2308/JETA-2020-060.

[5] Albitar, K., Gerged, A. M., Kikhia, H., and Hussainey, K. "Auditing in Times of Social Distancing: The Effect of COVID-19 on Auditing Quality." International Journal of Accounting \& Information Management, Vol. 29, No. 1, 2021, pp. 169-178. https://doi.org/10.1108/IJAIM-08-20200128.

[6] Đorđević, M., and Đukić, T. “Auditors' Responsibility in Assessing Going Concern Assumption Affected by Covid-19." Economic Themes, Vol. 59, No. 1, 2021, pp. 7793. https://doi.org/10.2478/ethemes-2021-0005.

[7] Pirlot, A., Collier, R., and Vella, J. "Tax Policy and the COVID-19 Crisis.” Intertax, Vol. 48, No. 8/9, 2020. https://doi.org/10.2139/ssrn.3646035.

[8] Ahrens, T., and Ferry, L. "Accounting and Accountability Practices in Times of Crisis: A Foucauldian Perspective on the UK Government's Response to COVID-19 for England." Accounting, Auditing \& Accountability Journal, Vol. ahead-of-print, No. ahead-of-print, 2021. https://doi.org/10.1108/AAAJ-07-2020-4659.

[9] Padhan, R., and Prabheesh, K. P. "The Economics of COVID-19 Pandemic: A Survey." Economic Analysis and Policy, Vol. 70, 2021.https://doi.org/10.1016/j.eap.2021.02. 012 .

[10] De Vito, A., and Gómez, J. P. "Estimating the COVID-19 Cash Crunch: Global Evidence and Policy." Journal of Accounting and Public Policy, Vol. 39, No. 2, 2020. https://doi.org/10.1016/j.jaccpubpol.2020.106741.

[11]Ekren, N., Aykaç Alp, E., Findikçi Erdogan, M., and Güner, Y. "The Impact of Covid-19 on the Firms: Results of the Thematic Survey Conducted by CSCPA of Istanbul." International Journal of Commerce and Finance, Vol. 7, No. 1,2021

[12] Lu, J., and Wang, J. “Corporate Governance, Law, Culture, Environmental Performance and CSR Disclosure: A Global Perspective." Journal of International Financial Markets,
Institutions and Money, Vol. 70, 2021, p. 101264. https://doi.org/10.1016/j.intfin.2020.101264.

[13] Kraus, S., Clauss, T., Breier, M., Gast, J., Zardini, A., and Tiberius, V. "The Economics of COVID-19: Initial Empirical Evidence on How Family Firms in Five European Countries Cope with the Corona Crisis." International Journal of Entrepreneurial Behavior \& Research, Vol. 26, No. 5, 2020, pp. 1067-1092.https://doi.org/10.1108/IJEBR-04-2 020-0214.

[14] Larcker, D. F., Lynch, B., Tayan, B., and Taylor, D. J. "The Spread of COVID-19 Disclosure." Stanford Closer Look Series, 2020.

[15] García-Sánchez, I. M., Raimo, N., Marrone, A., and Vitolla, F. "How Does Integrated Reporting Change in Light of COVID-19? A Revisiting of the Content of the Integrated Reports." Sustainability, Vol. 12, No. 18, 2020, p. 7605. https://doi.org/10.3390/su12187605.

[16] Loughran, T., and McDonald, B. "Management Disclosure of Risk Factors and COVID-19." SSRN Electronic Journal, 2020. https://doi.org/10.2139/ssrn.3575157.

[17] Tibiletti, V., Marchini, P. L., Gamba, V., and Todaro, D. L. "The Impact of COVID-19 on Financial Statements Results and Disclosure: First Insights from Italian Listed Companies.' Universal Journal of Accounting and Finance, Vol. 9, No. 1, 2021, pp. 54-64. https://doi.org/10.13189/ujaf.2021.090106.

[18] Honko, S., Remlein, M., Rowinska-Kral, M., and Swietla, K. "Effects of COVID-19 in the Financial Statements of Selected Companies Listed in Warsaw Stock Exchange." European Research Studies Journal, Vol. 23, No. 2, 2020, pp. 854-871.

[19] Waclawik, B. "Corporate Reporting in the Time of COVID-19: Analysis of Information Disclosed by Selected Companies Listed on the Warsaw Stock Exchange." European Research Studies Journal, Vol. 24, No. 1, 2021, pp. 386-402. https://doi.org/10.35808/ersj/2049.

[20] Schivardi, F., and Romano, G. "A Simple Method to Estimate Firms' Liquidity Needs during the Covid-19 Crisis with an Application to Italy." Covid Economics, Vol. 35, pp. 51-69.

[21]Blanco, R., Mayordomo, S., Menéndez Pujadas, Á., and Mulino Rios, M. The Impact of the Covid-19 Crisis on the Financial Position of Non-Financial Corporations in 2020: CBSO-Based Evidence.https://papers.ssrn.com/abstract=374 2646. Accessed Jun. 28, 2021.

[22] Acharya, V. V., and Steffen, S. "The Risk of Being a Fallen Angel and the Corporate Dash for Cash in the Midst of COVID." The Review of Corporate Finance Studies, Vol. 9, No. 3, 2020, pp. 430-471. https://doi.org/10.1093/rcfs/cfaa0 13.

[23] Fahlenbrach, R., Rageth, K., and Stulz, R. M. "How Valuable Is Financial Flexibility When Revenue Stops? Evidence from the COVID-19 Crisis." The Review of Financial Studies, No. hhaa134, 2020. https://doi.org/10.1093/rfs/hhaa134.

[24] Qin, X., Huang, G., Shen, H., and Fu, M. "COVID-19 Pandemic and Firm-Level Cash Holding-Moderating Effect of Goodwill and Goodwill Impairment." Emerging Markets Finance and Trade, Vol. 56, No. 10, 2020, pp. 22432258. https://doi.org/10.1080/1540496X.2020.1785864. 
[25] Matei, N. C. "Impact of the Crisis Generated by Covid-19 on Financial Reports Prepared in Accordance with National Regulations." Global Economic Observer, Vol. 8, No. 1, 2020, pp. 47-51.

[26] Guerini, M., Nesta, L., Ragot, X., and Schiavo, S. "Firm Liquidity and Solvency under the Covid-19 Lockdown in France.” OFCE Policy brief, Vol. 76, 2020.

[27] Carletti, E., Oliviero, T., Pagano, M., Pelizzon, L., and Subrahmanyam, M. G. "The COVID-19 Shock and Equity Shortfall: Firm-Level Evidence from Italy." The Review of Corporate Finance Studies, Vol. 9, No. 3, 2020, pp. 534-568. https://doi.org/10.1093/rcfs/cfaa014.

[28] Fu, M., and Shen, H. "COVID-19 and Corporate Performance in the Energy Industry." Energy RESEARCH LETTERS, Vol. 1, No. 1, 2020. https://doi.org/10.46557/00 1c.12967.

[29] Savova, K. "Global Impact of COVID 19 on the Concept of 'Going Concern.'” SHS Web of Conferences, Vol. 92, 2021. https://doi.org/10.1051/shsconf/20219201045.

[30] Buera, F. J., Fattal-Jaef, R. N., Hopenhayn, H., Neumeyer, P. A., and Shin, Y. The Economic Ripple Effects of COVID-19. Publication 28704. National Bureau of Economic Research, 2021.

[31] Dohrer, B., and Mayes, C. "Auditing during COVID-19: 6 Areas to Focus on; Practitioners and Their Clients Are Facing Challenges They Have Never Encountered Before." Journal of Accountancy, Vol. 229, No. 5, 2020, p. 14.

[32] Levy, H. B. "Financial Reporting and Auditing Implications of the COVID-19 Pandemic." The CPA Journal, Vol. 90, No. 5, 2020, pp. 26-33.
[33] Appelbaum, D., Budnik, S., and Vasarhelyi, M. "Auditing and Accounting During and After the COVID-19 Crisis." The CPA Journal, Vol. 90, No. 6, 2020, pp. 14-19.

[34] Kaka, E. J. "Covid-19 and Auditing." Journal of Applied Accounting and Taxation, Vol. 6, No. 1, 2021, pp. 1-10. https://doi.org/10.30871/jaat.v6i1.2311.

[35] Krasodomska, J., and Zarzycka, E. "Key Performance Indicators Disclosure in the Context of the EU Directive: When Does Stakeholder Pressure Matter?" Meditari Accountancy Research, Vol. 29, No. 7, 2020, pp. 1-30. https://doi.org/10.1108/MEDAR-05-2020-0876.

[36] Boujelben, S., and Boujelben, C. "Socio-Emotional Wealth Preservation and KPI Voluntary Disclosure Quality." Journal of Financial Reporting and Accounting, Vol. 18, No. 3, 2020, pp. 459-482. https://doi.org/10.1108/JFRA-09-2019-0113.

[37] Abutaber, T. A., Bzur, A. E. A., Odeh, M. H., Alathamneh, M., Al-Okaily, M., and Afaneh, M. K. "The Effect of Corporate Governance Indicators on Enhancing the Financial Performance of Industrial Listed Companies on the Amman Stock Exchange.” Accounting, Vol. 7, No. 2, 2021, pp. 415422. https://doi.org/10.5267/j.ac.2020.11.009.

[38] Rashid, A. "Corporate Social Responsibility Reporting: Meeting Stakeholders Expectations or Efficient Allocation of Resources?" International Journal of Accounting and Information Management, Vol. 29, No. 2, 2020, pp. 280-304. https://doi.org/10.1108/IJAIM-09-2020-0150.

[39] Castilla-Polo, F., and Ruiz-Rodríguez, C. "Content Analysis within Intangible Assets Disclosure: A Structured Literature Review." Journal of Intellectual Capital, Vol. 18, No. 3, 2017, pp. 506-543. https://doi.org/10.1108/JIC-11-2016-0123 